\title{
White Rhino Extinct in Uganda
}

\section{Eric L. Edroma}

The northern race of the square-lipped rhinoceros Ceratotherium simum cottoni is disappearing in Africa and is now believed extinct in Uganda. Commonly called the white rhinoceros because of its wide (weit) square mouth, it differs from the black rhino in size, habits and disposition. The white rhino occurred naturally in three countries: the West Nile Province of Uganda, north-east Zaire, and the Bahr el Ghazal and Equatorian provinces of Sudan. The Nile limited its eastern spread, although fossils show that it existed in Tanzania some 400,000 years ago. ${ }^{8}$ Its extreme southern limit was the river Ora which enters the Nile opposite Wadelai, from where it extended northwards along the western bank of the Nile through to Shambe ${ }^{17}$ and then north-west through the Bahr el Ghazal drainage to the borders of Chad, ${ }^{16}$ where in the 1890 s it was abundant. ${ }^{9}$ Harper reported the collection of many rhino horns yearly in Abecher. ${ }^{5}$ At the beginning of this century Sidney described the species as numerous in the upper waters of the Bahr Azoum and the Bahr Aoule, plentiful in the Birao area, fairly numerous north of the Uele river in what is today in Zaire's Garamba National Park, and abundant in Okolo, Aringa and West Madi in Uganda. ${ }^{18}$ Rhinos were so common in all these areas that in 1919 Theodore Roosevelt's headquarters for the Smithsonian African Expedition collecting rhino products was named Rhino Camp. ${ }^{1}$ Here in 1932 Captain Pitman encountered 30-40 groups of at least seven individuals each within a day's walk, and he could approach to within $7-8 \mathrm{ft}$ because they were unharried by hunters and poachers.

\section{Census in Uganda}

Attempts were made in 1925 and 1926 to census Uganda's white rhinos; before 1928 Pitman gave an average of 150 individuals in the West Nile Province. ${ }^{10}$ The 1928 census was the first reasonably accurate one in Uganda when at least 130 individuals were estimated. ${ }^{1}$ By 1939 Salmon estimated $220 .{ }^{14}$ After that, increased poaching and hunting, coupled with settlement and cultivation in supposed rhino range, caused a steady decline in the rhino numbers, and in 1948 only 190 animals were recorded. Around that time the animals left Rhino Camp and moved south into Ajai-Inde Swamps and north into Obongi. That year too the Game Department improved anti-poaching operations and there was optimistic talk of increased numbers. Pitman suggested that there were more rhinos in the Era Forest Reserve than in both the Mountain Kei and Otze Forest Sanctuaries combined. ${ }^{11}$ In 1949 he estimated 24 animals in the Mount Kei Reserve and 50 in the 60-square-mile strip between the Uganda border and the Nile in Sudan. ${ }^{12}$ In 1951, Sidney estimated over 300 animals, ${ }^{18}$ although others estimated $500 .{ }^{13}$ In the first half of the 1950s the Government reported the white rhino to be flourishing, especially in the Ajai-Inde Swamps, the Mount Kei and Otze Forest Sanctuaries. Animals in the Otze Sanctuary roamed at ease between Madi and Nimule Game Reserves in Sudan, and by 1955 the white rhino population was 350 .

The tragedy for the Uganda white rhinos started in 1956 when heavy poaching from Southern Sudan was widespread. The white rhino is a shy animal, retiring in temperament, the least observant of the big game, the easiest to approach and, 


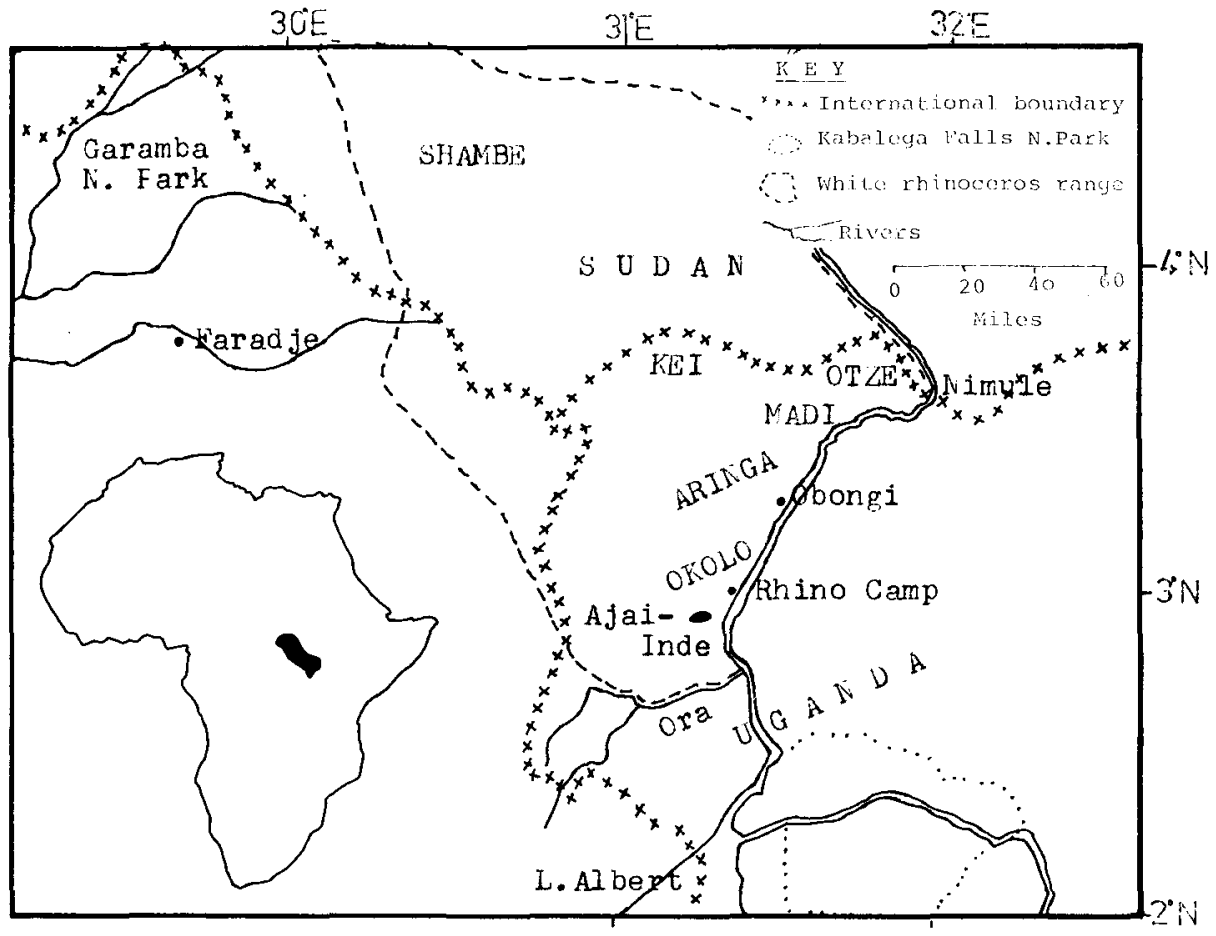

therefore, to poach. Improving road conditions and increasing human populations in once remote areas, made effective management of the animals difficult. The Mount Kei Sanctuary was said to contain few animals, and the population in Otze Forest Reserve retreated into the central and southern sections of the Otze Forest Sanctuary. In the Ogoko area poaching was so serious that the white rhino was reported to be dying out, and in 1957 few animals were reported in the Otze and Kei Sanctuaries. Only in the Ajai-Inde Swamps were they increasing, but even here they had not recovered from the heavy poaching of 1954.

In 1956 the Game Department and the National Parks considered introducing the species into Kabalega Falls National Park, where strict protection was assured,,$^{15}$ and in March 1961 ten animals were taken there. Four of the ten died, but in June 1964 six more were successfully translocated. These 12 animals were the nucleus of a population considered to be the only hope for the species' survival in Uganda. In the next ten years they multiplied, and by 1974 there were at least 30. ${ }^{7}$ But in the Ajai-Inde Swamps and the Otze and Kei Sanctuaries poaching was so heavy that the population dropped from over 335 in $1958^{6}$ to a mere 80 in $1962 .^{1}$ The East African Wildlife Society and WWF provided funds to establish the Ajai Game Reserve to give more stringent protection, but numbers continued to decline - as the table shows. By 1967 there were only 60 white rhino in Ajai Reserve, 18 in Kabalega Falls National Park and hardly any in the Otze and Kei Sanctuaries. ${ }^{4}$ In neighbouring Zaire Curry-Lindahl reported a massive decline from 1000 to 100 in the early $1960 \mathrm{ss}^{2}$ 
Numbers of White Rhinoceros in Uganda in the Past Century

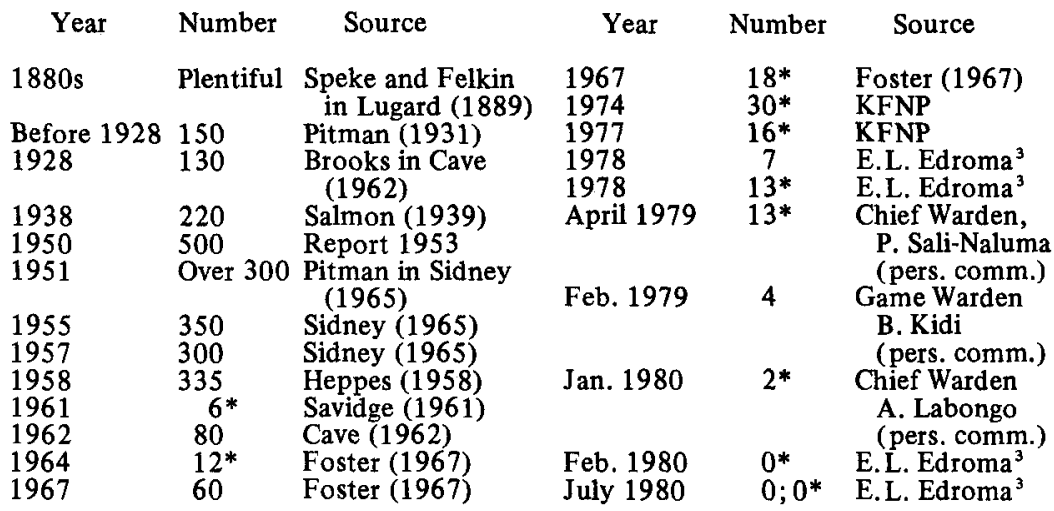

* Numbers in Kabalega Falls National Park only, following translocation of ten in March 1961 and six in June 1964 from Ajai Game Reserve into the Park.

In 1975 the National Wildlife Committee of Uganda regretfully recorded the white rhino absent in Mount Kei and Otze and other areas; a few survived in the Ajai Game Reserve and in the north-west sector of Kabalega Falls National Park. In February 1978 the present author found only six adults and one juvenile during a ground search in the Ajai. In an aerial elephant count in December 1978 the author recorded 13 rhinoceroses in Kabalega Falls Park, and they were still there in April 1979 (Mr Paul Ssali, pers. comm.). In February 1979 the Game Warden, Ben Kidi (pers. comm.) believed that no more than four white rhino survived in Ajai. During the 1979 liberation war the white rhinoceros was feared poached out of existence, and at the end of February 1980, during a three-hour aerial search, the author saw none, although two individuals had been reported by rangers six weeks previously. Again in April 1980, in an aerial census with Dr Douglas-Hamilton and Dr Malpas, none were seen, and in a final aerial survey in July 1980 none was seen in Kabalega Park or Ajai Game Reserve. Another independent ground count by Dr Malpas in May 1980 gave the same result and it is now concluded that the elegant white rhino has been eliminated from Uganda by the unscrupulous hand of man. The northern race survives there only in pictures and names such as Rhino Camp and White Rhino Hotel.

\section{Causes for Decline}

The reasons for the rhino's extermination are not difficult to identify. Until 1950 the decline was due to loss of the home range due to increasing human population, agricultural land use and illegal hunting, coupled with the rhino's relatively slow reproduction rate, which, under natural conditions, is once nearly every four years, although two-year intervals have been reported in zoos, and the unusually high infant mortality, which is very important in the wild.

The recent accelerated decline stems from the enormous value of rhino horn. Today one kilo of rhino horn fetches nearly US $\$ 700$ in East Africa and US\$950 in the Yemen and Far East countries. Law enforcement authorities have been unable to cope effectively with this problem. 


\section{Recommendations for Conservation}

Ugandan authorities have to tighten and step up measures to combat the prevalent poaching, and, in consultation with the Uganda government and the international conservation authorities, to plan a strategy for restocking former white rhino areas with animals from neighbouring Zaire or Sudan. Above all they have to rid the country of lawlessness. For without stability, efforts to conserve the wildlife will be futile.

\section{Acknowledgment}

I thank Professor Ross W. Wein for his constructive criticism during the preparation of the paper and for providing a working space in the Department of Biology, University of New Brunswick, Fredericton, Canada.

\section{References}

1. CAVE, A.J.E. 1962. The white rhino in Uganda. Oryx 1: 26-9.

2. CURRY-LINDAHL, K. 1966. The current situation in the Albert and Garamba National Parks, Congo. IUCN Bull. New Series 20: 3.

3. EDROMA, E. L. 1980. Road to extermination in Uganda. Oryx 15: 5, $451-2$.

4. FOSTER, J.B. 1967. The square-lipped thino in Uganda. E. Afr. Wildl. J. 5: $167-91$.

5. HARPER, F. 1945. Extinct and vanishing mammals of the Old World. Spec. Publ. Amer. Com. int. Wild. Protec. 12: 1-850.

6. HEPPES, J. 1958. Uganda Wild Life and Sport 1 (4): 29-35.

7. KFNP. 1974. Kabalega Falls National Park Annual Report, Uganda.

8. LEAKEY, L.S.B. 1965. Olduvai Gorge 1951-1961. Cambridge Unviersity Press.

9. LUGARD, F.D. 1889. The rise of our East African Empire. Vol. I. Frank Cass, London.

10. PITMAN, C.R.S. 1931. A Game Warden among his Charges. James Nisbet, London.

11. PITMAN, C.R.S. 1949. In: Annual Report of Game Dept., Uganda.

12. PITMAN, C.R.S. 1950. In: Annual Report of Game Dept., Uganda.

13. REPORT. 1953. Report of Game Department, Kenya.

14. SALMON, T.R.P. 1939. In: Annual Report of Game Dept., Kenya,

15. SAVIDGE, J. 1961. The introduction of white rhino into Murchison Falls National Park, Uganda. Oryx 6: 184-9.

16. SCLATER, P.L. 1903. Exhibition of the front horn of a rhino obtained on the White Nile. Proc. Zool. Soc. Lond. 2: 194.

17. SELOUS, R.C. 1893. Travel and adventure in south-east Africa. Rowland Ward, London.

18. SIDNEY, J. 1965. The past and present distribution of some African ungulates. Trans. Zool. Soc. Lond. 30: 51-87.

Dr Eric L. Edroma, Uganda Institute of Ecology, Box 22, Lake Katwe, Uganda.

\section{Fifty-One Years Ago}

Capt. H.C. Brocklehurst, Game Warden of the Sudan, wrote in Game Animals of the Sudan (1931) of the northern white rhino that its '... horn has an even higher marketable value than ivory, being used for making door handles, for the interiors of limousine motorcars and the hilts of presentation swords etc'. 


\section{What Hope for North Atlantic Right Whales? - A Correction}

The Editor very much regrets that the wrong references were published for the article 'What Hope for North Atlantic Right Whales?' in the last Oryx, Vol. XVI, No. 3, page 255. The correct list is printed here.

\section{References}

1. BEST, P. B. 1977. Rep. Int. Whal. Commn 27: 116-21.

2. BEST, P.B. In press. Investl Rep. Sea Fish. Inst. S. Afr.

3. MERMOZ, J.F. 1980. Rep. Int. Whal. Commn 30: 183-6.

4. PAYNE, R.S. and E.M. DORSEY. 1979. p. 46 in Abstr. 3rd Biennial Conf. Bio. Marine Mammals, Seattle, Wash.

5. ANONYMOUS. In press. Report of the Sub-Committee on Protected Species and Aboriginal Whaling. Rep. Int. Whal. Commn 32.

6. KLUMOV, S.K. 1962. Trudy Inst. Okeanol. 58: 202-97.

7. OMURA, H. et al. 1969. Sci. Rep. Whales Res. Inst. (Tokyo) $21: 1-78$.

8. BERZIN, A.A. and N.V. DOROSHENKO. 1981. Rep. Int. Whal. Commn 31: $451-5$.

9. WADA, S. 1980. Rep. Int. Whal. Commn 30: 415-24.

10. SCAMMON, C.M. 1874. The marine mammals of the north-western coast of North America, described and illustrated: Together with an account of the American whale-fishery. San Francisco: J.H. Carmany \& Co.

11. RICE, D.W. and C.H. FISCUS. 1968. Norsk Hval.-tid. 1968 (5): 105-7.

12. ROWNTREE, V. et al. 1980. Canadian J. Zool. 58: 309-12.

13. HeRMAN, L.M. et al. 1980. Mar. Ecol. Prog. Ser. 2: 271-5.

14. REEVES, R.R. et al. 1978. Rep. Int. Whal. Commn 28: 303-12.

15. ANONYMOUS, 1981. Rep. Int. Whal. Commn 31: 133-9.

16. EVANS, P.G.H. 1980. Mammal Rev. 10 (1): 1-52.

17. AGUILAR, A. 1981. Rep. Int. Whal. Commn 31: 457-9.

18. MARKHAM, C.R. 1881. Proc. Zool. Soc. London 1881: 969-76.

19. BARKHAM, S. 1977. Geogr. Mag. 49 (9): 574-81.

20. ESCHRICHT, D.F. and J. REINHARDT, 1866. pp. 3-150 in W.H. Flower (ed.), Recent Memoirs on the Cetacea. London: Ray Society.

21. HARMER, S.F. 1928. Proc. Linn. Soc. London 140: 51-95.

22. COLLETT, R. Norges pattedyr. Kristiania: A. Aschehoug \& Co.

23. GRAY, R.W. 1937: Naturalist 1937: 153-6.

24. ALLEN, J.A. 1908. Bull. Amer. Mus. Nat. Hist. 24 (18): 277-329.

25. AlleN, G.M. 1916. Mem. Boston Soc. Nat. Hist. 8 (2): 105-322.

26. EDWARDS, E.J. and J.E. RATTRAY. 1932. 'Whale off!' The story of American shore whaling. N.Y.: Frederick A. Stokes Co.

27. MITCHELL, E. and R.R. REEVES. 1981. Catch history, abundance, and present status of Northwest Atlantic humpback whales. Int. Whaling Commn, SC/33/PS14.

28. COLLETT, R. 1909. Proc. Zool. Soc, London 1909: 91-8.

29. THOMPSON, D'A.W. 1918. Scottish Nat. 1918: 197-208.

30. MOORE, J.C. 1953. A merican Mid. Nat. 49: 117-58.

31. LAYNE, J.N. 1965. Bull. Florida State Mus. (Biol. Sci.) 9 (4): 131-81.

32. SCHEVILL, W.E. et al. 1981. Right whale sightings in Cape Cod waters. Woods Hole Oceanographic Institution, Woods Hole, Mass. Tech. Rep. WHOI-81-50.

33. WATKINS, W.A. and W.E. SCHEVILL. 1976. J. Mammal. 57: 58-66.

34. WATKINS, W.A. and W.E. SCHEVILL. 1979. J. Mammal. 60: 155-63.

35. WATKINS, W.A. and W.E. SCHEVILL, pers. comm.

36. ANONYMOUS. 1981. A characterization of marine mammals and turtles in the mid- and north-Atlantic areas of the U.S. Outer Continental Shelf. 
Executive summary for 1979 for the Cetacean and Turtle Assessment Program, Univ. of Rhode Island, Kingston, R.I. 02881, USA.

37. WINN, H.E. et al. 1981. Chapter VI in A Characterization of Marine Mammals and Turtles in the Mid- and North-Atlantic Areas of the U.S. Outer Continental Shelf. Annual Report for 1979 for the Cetacean and Turtle Assessment Program, University of Rhode Island, Kingston, Rhode Island.

38. ANONYMOUS. 1980. CETAP Newsletter. Univ. of Rhode Island. 4 p.

39. KRAUS, S.D. and J.H. PRESCOTT. 1981. Distribution, abundance and notes on the large cetaceans of the Bay of Fundy, summer and fall 1980. Final report to USDC, NOAA, National Marine Fisheries Service, Woods Hole, Massachusetts. 87 pp unpubl. manuscript. (Revised 1 June 1981.)

40. NEAVE, D.J. and B.S. WRIGHT. 1968. J. Mammal. 49: 259-64.

41. ARNOLD, P.W. and D.E. GASKIN. 1972. J. Fish. Res. Bd. Canada 29: 1477-8.

42. SERGEANT, D.E. 1966. Fish. Res. Bd. Canada, Circular 9: 1-13.

43. ANONYMOUS. 1961. International whaling statistics XLV. Edited by The Committee for Whaling Statistics, Oslo.

44. MAUL, G.E, and D.E. SERGEANT. 1977. Bocagiana 43: 1-8.

45. CALDWELL, D.K. and M.C. CALDWELL. 1971. Cetology 4: 1-6.

46. REEVES, R. 1976. New Jersey Audubon 2 (1): 7-14.

47. SCHMIDLY, D.J. et al. 1972. Southwest. Naturalist 17: 214-5.

48. KATONA, S. pers. comm.

49. MEAD, J.G. pers. comm.

\section{Arctic Reserve Threatened}

Polar Bear Pass on Bathurst Island, one of 27 sites identified by the International Biological Programme in 1974 for ecological reserves in the High Arctic and given temporary protection by the Canadian Government in 1978, should be formally declared and protected, says the Government's working group's report. But, it adds, 'alternative land uses could be accommodated at the site without serious disruptions to the ecological values'. As this is likely to mean mining, oil and gas exploration and pipelines, Canadian conservationists are fighting the proposal, which would destroy the purposes of the reserve and also create a dangerous precedent. Polar Bear Pass is an important calving and wintering ground for musk oxen and a migration route for caribou.

\section{New Antarctic Convention}

Ratification by New Zealand on 8 March brought the Convention on Antarctic Marine Resources into force on 7 April, and the first meeting of the parties to the convention is now scheduled for Hobart, Tasmania, in May 1982, The British non-governmental organizations (ngo's), operating through Wildlife Link, have asked the British Government for representation on the UK delegation. However, the Falkland Islands situation has thrown doubt on such a meeting.

\section{Extinction on the Way?}

A three-day aerial census last October of Kafue lechwe Kobus leche kafuensis on the Kafue Flats, in Zambia, showed numbers down by more than half since the last census in 1975: from 80,000 to 34,000. In a detailed account of the lechwe situation, published in Oryx, December 1980, 'Will the Kafue Lechwe Survive the Kafue Dams?', Richard Schuster suggested that the demand for electricity meant that floods on the Flats would be controlled in the interests of electricity not wildlife and that the Kafue lechwe would probably become extinct. Is he being proved right? 